\title{
Plantar, Pastorar e Fiar na Vila Formosa de Alfenas, MG: Décadas de 1850-1890
}

\author{
Marcos Lobato Martins \\ Professor - Instituto de Ciências Humanas e Letras - Universidade Federal de Alfenas (UNIFAL-MG) \\ Endereço para contato: Rua Gabriel Monteiro da Silva, 100 - Alfenas - MG \\ CEP: 37130-000 - E-mail: marcos.lobato@unifal-mg.edu.br
}

Recebido em 19 de janeiro de 2011 . Aceito em 17 de agosto de 2012.

\section{Resumo}

A região do Sul de Minas, hoje conhecida como a principal área cafeeira do país, era, no decurso do século XIX, zona destacada de agricultura de abastecimento. A criação de gado e a produção de mantimentos eram as principais atividades econômicas regionais. A cafeicultura, introduzida em meados do século XIX, promoveu gradual modificação do cenário regional. Porém, esta transição para a agricultura de exportação, que ocorreu na virada para o século XX, ainda é pouco conhecida, especialmente no que se refere às alterações nos sistemas agrários e na composição das fortunas dos proprietários. A análise desse processo no antigo município de Alfenas é o objetivo deste artigo. As fontes utilizadas são inventários e documentos cartorários.

\section{Palavras-Chave}

agricultura diversificada, propriedades e fortunas rurais, Alfenas, sul de Minas

\begin{abstract}
The region of South of Minas, that today knew as principal coffee area of the country, was detached zone of the diversified agriculture in nineteenth century. The cattle breeding and the food production were main regional economic activities. The coffee, introduced in second half of the nineteenth century, promoted gradual modification in the regional scene. However, this transition for export agriculture, that occurred in the turn for twentieth century, is yet little know, specially in reference to transformations in the agrarian systems and in the composition of the proprietors' fortunes. The analysis this process in Alfenas municipality is the aim of this paper. The founts utilized are inventories and registry documents.
\end{abstract}

\section{Keywords}

diversified agriculture, rural proprieties and fortunes, Alfenas, south of Minas

\section{JEL Classification}

N56, N96

- O autor agradece a FAPEMIG pelo financiamento do projeto "As transformações do campo sul-mineiro na virada para o século XX: a transição da agricultura diversificada para a agroexportação do café". 


\section{Introdução}

Este trabalho é produto inicial de uma pesquisa sobre a transição da agricultura de abastecimento para a agroexportação cafeeira na região Sul de Minas, abrangendo o período compreendido entre as décadas de 1850 e 1890. O objetivo é avançar algumas considerações referentes à implantação da cafeicultura na região, dialogando com questões presentes na historiografia mineira e brasileira a partir da análise de escrituras e procurações, encontradas no Cartório do $1^{\circ}$ Ofício da Comarca de Alfenas, e de inventários pertencentes ao acervo do antigo Juízo de Órfãos e Ausentes do Termo de Alfenas. Trata-se, portanto, de exploração inicial da referida documentação orientada por duas questões:

a) Quando, por quem e como a cultura comercial do café começou a ganhar relevância nas terras do município de Alfenas (mapa na página 404)?

b) Quais transformações a entrada do café nas fazendas de Alfenas provocou no uso das terras e dos recursos econômicos disponíveis aos proprietários?

Ao atentar para as especificidades existentes no Sul de Minas, este texto propiciará a retomada do debate historiográfico sobre temas importantes da história econômica e social, na perspectiva dos estudos regionais que favorecem a comparação entre espaços distintos, do que muitas vezes resulta a revisão de teses consagradas, o questionamento e a crítica de narrativas e interpretações dominantes (Goubert, 1992).

\section{Da Agricultura de Abastecimento à Cafeicultura}

Caio Prado Jr assinalou a importância da agricultura mercantil de abastecimento nas regiões sul-mineiras no fim do século XVIII e início do século XIX. É bastante conhecido o trecho em que o historiador paulista escreveu:

"Reúne-se neste sul de Minas um conjunto de circunstâncias muito favoráveis à criação de gado; e logo que a região começa a ser devassada pelos exploradores do ouro, inicia-se pa- 
ralelamente uma atividade rural em que se destacará a pecuária. Esta chamará a si, aos poucos, o mercado próximo que os centros mineradores em formação lhe vão proporcionando. (...) O sul de Minas suprirá em seguida, e substituirá, afinal, os fornecedores do Rio de Janeiro: os Campos dos Goitacases e os mesmos Campos-Gerais citados; estes ficam mais longe, aqueles transformam seus pastos em canaviais. É em 1765 que descem para o Rio de Janeiro os primeiros gados da nova proveniência. Até São Paulo, vizinho embora dos Campos meridionais, se abastecerá em Minas." (Prado Jr., 1972, p. 198)

Na linha de Caio Prado Jr. segue o trabalho de Alcir Lenharo (1979), estudo clássico sobre a região. Lenharo sustentou que, entre 1808 e 1842, o Sul de Minas foi o principal abastecedor do mercado carioca, para o qual produzia e exportava grande quantidade de gado em pé, além de porcos, galinhas, carneiros, toucinhos, queijos e cereais. Mais de uma vez, Alcir Lenharo realçou a importância do Senador Padre José Custódio Dias e da Fazenda do Centro no negócio de reses que abastecia a Corte. José Custódio Dias era filho de Custódio José Dias, grande proprietário no distrito de São José e Dores de Alfenas, sobre o qual consta, em lista de 1831, possuir um engenho de cana, para açúcar e aguardente, com 2 empregados livres e 34 cativos; um engenho de serrar madeira, com 2 cativos, um engenho de pilóes, de fazer farinha, com 2 cativos; um moinho de mamona, para azeite, com 2 cativos e uma olaria, para telhas e tijolos, com 4 cativos. Como estes dois personagens, a região abrigava outras figuras componentes de uma elite rural que alcançou prestígio social e político nas primeiras décadas do século XIX, participando ativamente do processo de independência do Brasil. As atividades destes proprietários, relacionadas ao abastecimento da Corte, possibilitaram, como salientou Lenharo, a construção de redes sociais que os inseriram nos círculos políticos ligados à construção inicial do Estado brasileiro.

Para Robert Slenes (1985), o Sul de Minas oitocentista era capaz de gerar renda expressiva graças à agricultura de abastecimento e ao avanço da lavoura cafeeira, renda esta que, além de estimular 
a demanda interna, possibilitou à região importar grande número de escravos entre 1870 e 1880. Douglas Cole Libby (1988) também ressaltou o dinamismo da economia sul-mineira no decurso dos Oitocentos, vinculando-o estreitamente com a produção agropecuária e a indústria doméstica de tecidos. Por sua vez, Afonso de Alencastro Graça Filho (2002) estudou detalhadamente a praça mercantil de São João Del Rei e suas vinculações com o Rio de Janeiro, realçando o dinamismo dos homens de negócio daquela cidade e sua influência sobre vastas áreas da Província de Minas Gerais, especialmente o Oeste e a Zona da Mata.

No entanto, a partir dos anos 1870, esse perfil regional começou a ser alterado. Modificação causada pela introdução da cafeicultura que, em poucos decênios, transformou a região numa área de agroexportação. Nesse novo contexto, o Sul de Minas adquiriria, nas primeiras décadas do século passado, lugar proeminente na economia e na política mineira (Wirth, 1982). Há autores que sugerem que a cafeicultura sul-mineira seja simples projeção da cafeicultura do Oeste Paulista, caso de Paul Singer (1968). Este autor acredita que a cultura sulina originou-se do Vale do Paraíba paulista, expandindose por Jacuhy, Aiuruoca, Baependi e Santa Rita do Sapucaí. Singer assinala o ano de 1809 como a data de início das exportações sulmineiras de café pelo porto de Santos.

Dele diverge, todavia, Daniel de Carvalho, estudioso mineiro para quem o café no Sul de Minas teria sido introduzido através do Caminho Novo, poucos anos após sua entrada na Zona da Mata (apud Barbosa, 1972, p. 221). Para Carvalho, até 1826, a produção de café no Sul de Minas era insignificante e não dava para o consumo local. O trabalho de João Heraldo Lima (1981), que estuda as relações entre cafeicultura e industrialização na Zona da Mata mineira, contém algumas observações sobre a lavoura cafeeira no Sul de Minas. Uma delas diz respeito à reduzida participação da região no total das exportações mineiras de café pelo porto de Santos, nos anos 1890. Outra observação de João Heraldo Lima, anotada sem maiores explicações, sugere que a cafeicultura sul-mineira teria sido projeção da cafeicultura do Oeste Paulista. Nas palavras do autor:

"A expansão da fronteira [do café] também esbarraria em um sério obstáculo. (...) Poderíamos pensar numa expansão em direção ao sul do Estado. Entretanto, dada a proximi- 
dade dessa região com São Paulo, seria difícil imaginar um deslocamento das bases de acumulação para o sul de Minas em função dos elevados níveis em que ela se processava no Oeste paulista neste período. (Lima, 1981, p.18)

O argumento de Lima parece descartar origens mineiras para a cafeicultura no Sul de Minas. Para este autor, ela não poderia resultar de iniciativas dos fazendeiros da Zona da Mata, pois as estreitas bases da acumulação cafeeira nesta região teriam impedido qualquer tentativa de expandir a atividade além dos seus limites. Muito menos os senhores do Sul de Minas poderiam ter realizado a implantação da cafeicultura na região, uma vez que mais estreitos ainda seriam os excedentes gerados pela tradicional agricultura de abastecimento vis a vis a cafeicultura da Zona da Mata.

Em contraste com a posição de João Heraldo Lima, Roberto Borges Martins e Maria do Carmo Salazar Martins (1994) sugerem que a cafeicultura sul-mineira teria sua expansão associada à desorganização da produção na Zona da Mata mineira, em decorrência da abolição da escravidão. Posição que tanto implica a ideia de predomínio do trabalho livre nos cafezais do Sul de Minas quanto a permanência, até bem adiantado o século XIX, do sistema agrário típico da agricultura mercantil de abastecimento. Para Filleto (2000), nem Lima nem os Martins têm razão. Haveria dois vetores distintos relacionados à introdução da lavoura cafeeira no Sul de Minas, cujos resultados teriam sido modestíssimos até fins do século XIX. Conforme este autor, a trajetória da cafeicultura dos vales dos rios Sapucaí, Lourenço Velho, Verde e Grande seria dependente do Rio de Janeiro; já a cafeicultura do vale do Rio Pardo, altiplanos de Poços de Caldas, médio e baixo vales do Rio Grande e do Camanducaia seria dependente de São Paulo. Todas essas suposições carecem de comprovação empírica, baseada no exame de volumosa documentação local.

As referências ao café nas obras de memorialistas da região não ajudam muito a esclarecer os problemas mencionados. De modo geral, os textos memorialísticos convergem no sentido de apontar as décadas de 1860 e 1870 como período de introdução da lavoura cafeeira no Sul de Minas, bem como das primeiras exportações do "ouro verde" para o Rio de Janeiro. Moacyr Brêtas Soares (1940), autor de 
crônica histórica de Muzambinho, assinala que o café foi introduzido naquela localidade na década de 1840 :

Além de Pedro de Alcântara Magalhães, outro fazendeiro em evidência era José Alves do 'Cafesal'. As aspas do seu último nome são sugestivas. Foi ele quem primeiro cuidou do plantio do 'ouro verde', doze anos antes da fundação de São José da Boa Vista [ocorrida em 1852]. Foi por iniciativa sua que ali se plantaram os primeiros pés da fanatizante rubiácea - a monocultura de que cuidaram os brasileiros até há bem pouco tempo. José Alves do 'Cafesal' serviu-se de sementes que adquirira na Zona da Mata (...) para formar sua lavoura de café. (Soares, 1940, p. 20)

Este memorialista afirma ainda que o café transformou-se, nos anos 1880, na atividade predominante na região (Soares, 1940, p. 1112). Em direção semelhante aponta o trabalho de Ricardo Moreira Rebello (2006), corografia referente ao município de Machado. Conforme Rebello, o café fora introduzido no território da Vila de Campanha no início da década de 1820 . Na década de 1870 já existiriam, apenas na freguesia de Machado, 220 mil cafeeiros plantados por proprietários locais, com exportação para Rio de Janeiro e São Paulo. Para Maria Lúcia Prado Costa (2002), a expansão do café nos municípios de Alfenas e Pouso Alegre teria ocorrido em finais dos anos 1860 e começo da década de 1870, por meio de investimentos em cafezais de porte considerável, realizados por destacados fazendeiros há muito tempo estabelecidos nas terras sul-mineiras. Ela sugere, portanto, que teria ocorrido rápida e consciente especialização produtiva na região, além de assinalar a convivência do trabalho escravo com o trabalho livre imigrante (italiano) na cafeicultura sul-mineira. ${ }^{1}$

1 Segundo Mário Leite (1961) e Vera Alice Cardoso Silva (1982), a cafeicultura do Sul de Minas teria utilizado mão de obra imigrante. Manuel Diegues Júnior, além de assinalar a origem paulista da cafeicultura sul-mineira, também enfatiza a presença do trabalhador imigrante: "o café do Sul de Minas instalou-se sobre influência paulista, tanto na técnica de plantio quanto no gênero de vida. O próprio regime de trabalho, baseado na mão de obra imigrante e não mais no escravo, fixou-se no Sul de Minas" (apud. Resende, 1982, p. 378). 
Na historiografia brasileira há, por assim dizer, "modelos" diferentes para a trajetória da cafeicultura no Sudeste. No caso do Vale do Paraíba fluminense, Stanley Stein (1990) e João Fragoso (1992) mostraram que o café foi introduzido por famílias enriquecidas no comércio de "grosso trato" e na mineração. Nesta região pioneira da cafeicultura, a rubiácea foi cultivada em grandes propriedades e com uso de escravaria numerosa, deslocando violentamente os posseiros e sitiantes que ocupavam a região. Para o caso do Vale do Paraíba paulista, Marcondes (1998) mostrou que o café começou como lavoura secundária entre pequenos e médios proprietários voltados para a produção de alimentos - uma estratégia de diversificação das atividades. Porém, com o êxito da cafeicultura fluminense, grandes proprietários paulistas assumiram a liderança da lavoura de café no Vale do Paraíba em São Paulo, promovendo, então, a especialização produtiva regional. No Centro e no Oeste Paulista, conforme Dean (1977), Nozoe e Motta (1994), a cafeicultura foi introduzida por grandes proprietários vinculados anteriormente aos negócios com gado e cana-de-açúcar, de modo que novo sistema agrário, baseado em latifúndios e volumosa escravaria, teria se constituído nessas regiões, que, a partir de 1870 , caminharam rapidamente para a liderança do setor. Dean assinala também a participação importante de cabedais oriundos de São Paulo e do Rio de Janeiro no financiamento da cafeicultura da zona de Rio Claro.

Por sua vez, Mônica Ribeiro de Oliveira (2005) estudou o caso da Zona da Mata mineira, mostrando que a cafeicultura foi implantada por grandes proprietários, originários dos termos de Barbacena e São João Del Rei. Os cafezais foram implantados com capitais acumulados anteriormente nas atividades de abastecimento, sendo reduzida a participação de financiamentos da praça carioca. Ao redor de Juiz de Fora, grandes fazendas - que empregaram muita escravaria e tropas de muares para o transporte de café - conservaram roças e criações de animais para autoabastecimento e conviveram com fazendas voltadas para a produção de mantimentos. Dessa forma, na Zona da Mata mineira surgiu sistema agrário diferenciado tanto do Vale do Paraíba quanto do Oeste Paulista.

Esta rápida revisão da historiografia referente ao café e ao Sul de Minas evidencia que há muito a ser esclarecido sobre as transformações que afetaram a região durante a segunda metade do século XIX. 


\section{Propriedades Rurais de Alfenas nas Décadas de 1850 a 1890}

No ano de 1874, Bernardo Saturnino da Veiga, editor do influente periódico campanhense Monitor Sul-Mineiro, forneceu descrição da situação do município de Alfenas. Nessa década, o território do município incluía os seguintes distritos ou termos: São Sebastião do Areado (atual município de Areado), Carmo da Escaramuça (atual município de Paraguaçu), Douradinho (hoje distrito do município de Machado), São Francisco de Paula do Machadinho (atual município de Poço Fundo), Machado, São Joaquim da Serra Negra (atual município de Alterosa), São João do Barranco Alto (atual distrito de Alfenas) e Serrania. No ano de 1874, a cidade de Alfenas possuía cerca de trezentas casas, oito ruas e quatro praças, das quais a da Matriz e a do Rosário constituíam o centro da pequena urbe (Almanach Sul-Mineiro para 1874 , p. 2).
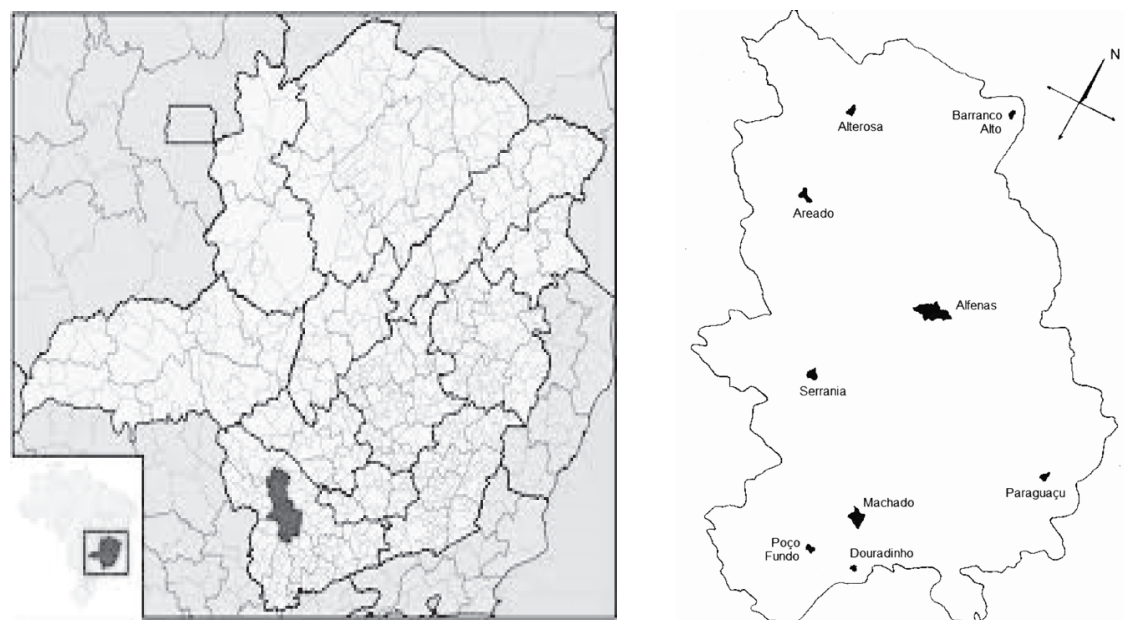

Figura 1 - Localização do município de Alfenas (década de 1870)

A propósito das atividades agropecuárias praticadas no município, o Almanach dizia que:

A cultura principal é ainda a dos gêneros alimentícios, fumo, cana, etc. Nos subúrbios [da cidade] há excelentes pastagens de angola e gordura, onde são engordadas inúmeras cabeças de gado vacum, cavalar e muar, especialmente o primeiro que forma o seu mais 
importante ramo de comércio, e do qual exporta anualmente para o Rio de Janeiro cerca de 4.000 reses. (p. 30)

Embora não gerasse "extraordinária exportação" como o gado e o toucinho, o algodão é citado pelo Almanach como outro produto que Alfenas comercializava. Referência especial era feita à freguesia de Carmo da Escaramuça, nos seguintes termos: “(...) como indício do lisonjeiro desenvolvimento que vai tendo a indústria da freguesia vêem-se já magníficos tecidos e lã, aliás fabricados nos antigos e grosseiros teares." (p. 33) Já em São Sebastião do Areado, o Almanach destacava que "as abelhas são geralmente criadas com esmero, colhendo-se todos os anos muito mais de cem arrobas de cera, e fabricando-se velas." (p. 34)

O município de Alfenas também mantinha ativo comércio com áreas vizinhas, servindo-se dos rios Sapucaí e Machado. Por meio de barcos de remos, localidades como Passos, Piumhi, Pouso Alegre e Itajubá recebiam de Alfenas algodão, toucinho, fumo, rapaduras, aguardente e toda sorte de mantimentos; em contrapartida, Alfenas recebia destes municípios principalmente sal e outros gêneros (Almanach Sul-Mineiro para 1874, p. 4-5).

Quanto ao importante distrito de Santo Antônio do Machado, o Almanach informava que o lugar possuía 14 ruas, 5 becos e 271 casas, onde viviam 1.173 pessoas. Conforme esta fonte:

Dessa freguesia exporta-se anualmente, termo médio, o número de 4 mil rezes gordas que, ao preço de 50\$000 a arroba, soma a quantia de 200 contos de réis. Exporta-se também pelo menos 25 mil arrobas de toucinho, que, ao preço de $5 \$ 000$ cada, produzem a soma de 110 contos de réis. Já existem plantados na freguesia 250 mil pés de café, que em grande parte já estão dando frutos, em qualidade igual ao das províncias do Rio e São Paulo, como o tem provado o seu uso. (p. 145) 
Documentos cartorários da década de 1870 revelam a continuidade da estrutura diversificada da produção agropecuária, herança do período de auge da economia de abastecimento. Por isso mesmo, o cotidiano rural de Alfenas era atravessado por problemas relativos a rebanhos e terras de cultivo. A título de exemplo, arrolam-se a seguir antigas procurações que mostram a importante presença do gado nas propriedades da época. Em 2 de outubro de 1877, João Quintino da Fonseca, morador de Carmo da Escaramuça, contratou um advogado para defendê-lo de ação movida por Francisco Gonçalves Leite, morador de Alfenas, referente à cobrança acerca da venda de um rebanho de porcos (Cartório do $1^{\circ}$ Ofício, Caixa 1 , Livro 1 de Lançamento de Procurações, p. 67). Em 18 de maio de 1878, Sertório Augusto de Faria e Sá nomeou seu procurador, o Dr. Severino Eulogio Ribeiro de Miranda, a fim de que pudesse tratar de uma ação civil contra Elias Bonifácio de Miranda para lhe fazer efetiva entrega de 37 rezes que este último tirara de suas capoeiras, ou fazer-lhe o pagamento da quantia de 1:850\$000, além das mais perdas e danos (Cartório do $1^{\circ}$ Ofício, Livro 1 de Lançamento de Procurações, p. 95-95v). Noutra procuração, datada de 14 de junho de 1878, Domingos Augusto Ferreira da Silveira reclama de danos e extravios sofridos por seu rebanho e plantações diversas provocados por seus vizinhos, em decorrência do descuido com cercas nas propriedades confrontantes (Cartório do $1^{\circ}$ Ofício, Caixa l, Livro 1 de Lançamento de Procurações, p. 97-97v).

As escrituras de compra e venda também fornecem claras indicações da diversificação produtiva que caracterizava as propriedades rurais do município. Uns poucos exemplos bastam para ilustrar este ponto. Em 6 de março de 1871, Manoel Galdino do Prado, grande negociante e fazendeiro residente em Alfenas, adquiriu de João Gomes de Azevedo três partes de terras da Fazenda da Estiva, situada a meia légua de Alfenas, pelo preço de 2:500\$000, compreendendo as benfeitorias ali existentes que eram uma casa coberta de telhas, monjolo, rego d'água com o competente açude, roças de arroz, cana e milho (Cartório do $1^{\circ}$ Ofício, Caixa 1, Livro de Protestos n 1 , p. 0-1). Martinho Gonçalves Leite adquiriu, em 21 de março de 1871, uma propriedade do Major Francisco de Paula Ferreira Lopes Sobrinho e sua mulher pelo preço de $800 \$ 000$. Tratava-se de chácara nos subúrbios do distrito de Alfenas, conhecida pelo nome "A Olaria", composta de capoeiras, campos e com uma fábrica de telhas (Cartório do $1^{\circ}$ Ofício, Caixa 1 , Livro de Protestos $n^{\circ} 1$, p. 4-4v). No mesmo 
ano, Domiciano Ferreira de Carvalho negociou com os irmãos Justino Alves Pedroza e Antônio Justino Alves Pedroza, respectivamente nas datas de 22 de abril e 23 de abril de 1871, a compra de fazendas situadas em Alfenas. De Justino, Domiciano adquiriu, por 8:500\$000, a fazenda denominada Pântano e, de Antônio, Domiciano comprou uma parte de terras de campo e cultura na fazenda denominada Charneca, pela quantia de 550\$000, ambas sem rezes (Cartório do $1^{\circ}$ Ofício, Caixa 1, Livro de Protestos nº 1, p. 6v-8v). Por sua vez, o Capitão Francisco Vieira Guimarães adquiriu, pelo valor de quatrocentos mil réis, de doze vendedores, todos pertencentes a uma mesma família, uma sorte de terras situadas na Fazenda de São Tomás, no lugar denominado Pinheirinho, distrito de Alfenas, que possuía mais de alqueire e meio e um fundo de brejos, onde existia uma casa de morada, monjolo e rego d'água, roças de arroz, feijão e milho. A referida negociação ocorreu em 13 de Julho de 1871 (Cartório do $1^{\circ}$ Ofício, Livro de Protestos $n^{\circ} 1$, p. $14 v-15 v$ ). O que se vê nas escrituras citadas? Que nas fazendas alfenenses podiam ser encontradas lavouras de mantimentos, pastagens e atividades industriais tradicionais (fiação e tecelagem, fabricação de farinhas, aguardente e objetos de ferro, conforme o Anexo 1), combinação típica dos sistemas agrários mineiros do período colonial (Menezes, 2000; Carrara, 1997).

O recurso aos inventários post-mortem possibilita avançar números para melhor definir a gama de perfis das propriedades rurais de Alfenas. Isto porque os inventários permitem analisar mais detalhadamente as estruturas produtivas das unidades rurais e a composição das fortunas dos proprietários (Furtado, 2009). Faremos a seguir algumas inferências relativas a estes assuntos, baseadas na análise de um conjunto de 65 inventários originalmente produzidos pelo Juízo de Órfãos e Ausentes do Termo de Alfenas. ${ }^{2}$

O Anexo 1 apresenta quadro das atividades produtivas nas quarenta e três unidades rurais do município de Alfenas mencionadas nos inventários, englobando as informações disponíveis para fazendas de tamanhos bastante variados. O que salta aos olhos é a presença marcante da produção de mantimentos (especialmente de milho, feijão

2 Os inventários oitocentistas do acervo da atual Vara de Família e Sucessões do Foro de Alfenas estão guardados em caixas não numeradas, sem critério ou organização, inexistindo qualquer instrumento de pesquisa que facilite a consulta. Estima-se que existam cerca de 200 inventários relativos à segunda metade do séc. XIX. Uma das tarefas realizadas no decorrer da pesquisa, à medida que são abetas as caixas, é a de gerar catálogo desta documentação. Os 65 inventários utilizados são assim distribuídos: 12 dos anos 1850, 10 dos anos 1860, 21 dos anos 1870, 14 dos anos 1880 e 8 dos anos 1890 . 
e arroz) e da criação de gado bovino e suíno. As roças de milho estão assinaladas na esmagadora maioria das fazendas, a cana aparece em um terço delas, ao passo que o café é encontrado em pouco mais da décima parte das fazendas. Pastos e gado bovino aparecem em praticamente todas as fazendas, enquanto a criação de suínos é registrada em mais da metade delas. A tabela seguinte apresenta informações sobre as atividades mais destacadas nas fazendas alfenenses da época:

Tabela 1 - Atividades produtivas nas fazendas de Alfenas (1855-1890)

\begin{tabular}{|c|c|c|}
\hline Atividades & $\mathrm{N}^{0}$ de ocorrências & $\%$ sobre o total \\
\hline Lavouras & $\begin{array}{c}14 \\
35 \\
6 \\
\end{array}$ & $\begin{array}{l}32,6 \\
81,4 \\
14,0\end{array}$ \\
\hline $\begin{array}{l}\text { Bovinos Criação de animais } \\
\text { Suínos }\end{array}$ & $\begin{array}{l}40 \\
26\end{array}$ & $\begin{array}{l}93,0 \\
60,5\end{array}$ \\
\hline $\begin{array}{l}\text { Atividades de transformação } \\
\text { Fiação e/ou tecelagem } \\
\text { Fabricação de farinhas } \\
\text { Fabricação de acúcar, rapadura cachaça }\end{array}$ & $\begin{array}{l}23 \\
20 \\
12\end{array}$ & $\begin{array}{l}53,5 \\
46,5 \\
27,9\end{array}$ \\
\hline
\end{tabular}

Fonte: Inventários do Juízo de Órfãos e Ausentes do Termo de Alfenas.

Na tabela anterior convém notar a significativa presença de atividades de beneficiamento e/ou transformação de matérias primas agrícolas. Como se pode ver no Anexo 1, destacavam-se as aparelhagens necessárias para a fabricação de farinhas (de milho e de mandioca), açúcar, rapadura e aguardente, bem como a permanência da capacidade de fiar e tecer panos grossos de algodão. As rodas de fiar e os teares apareciam em mais da metade das fazendas inventariadas; os monjolos e moinhos apareciam em quase metade das fazendas; os engenhos existiam em um quarto das fazendas e havia alambiques em $10 \%$ delas.

A criação de animais, que constituía atividade consorciada na maioria das fazendas de Alfenas, representava talvez a maior fonte de renda para as propriedades. Uma prova disto é fornecida pelo inventário de Antônio Ribeiro da Silva, proprietário da Fazenda Tamanduá, situada no arraial de São Joaquim da Serra Negra. Na relação de bens deste fazendeiro, morto em 1862, cuja soma alcançava 30:138\$690 rs, havia, em dinheiro corrente, a quantia de $756 \$ 250$ rs, resultantes da venda de porcos no referido ano (Juízo de Órfãos e Ausentes do Termo de Alfenas. Inv. de Antônio Ribeiro da Silva, 1862, fls. 9v-10v). Os números da pecuária são mostrados na tabela abaixo: 
Tabela 2 - Rebanhos em Alfenas (1855-1890)

\begin{tabular}{|c|c|c|c|c|}
\hline Rebanho & N. de animais & N. de proprietários & Média de posse & \% total de animais \\
\hline Bovino & 694 & 40 & 17,35 & 39,75 \\
\hline Suíno & 805 & 26 & 30,96 & 46,11 \\
\hline Equino/Muar & 102 & 28 & 3,64 & 5,84 \\
\hline Ovino & 145 & 17 & 8,53 & 8,30 \\
\hline Total & 1.746 & 43 & - & 100 \\
\hline
\end{tabular}

Fonte: Inventários do Juízo de Órfãos e Ausentes do termo de Alfenas.

As médias de bovinos e suínos nas propriedades de Alfenas mostravam-se bem inferiores às de outras áreas do Sul de Minas. Para o termo de Campanha, no período 1850-1867, Marcos Ferreira de Andrade (2008, p. 97) encontrou média de bovinos por fazenda de 77 cabeças. Para a freguesia de Itajubá, no período 1785-1850, Juliano Custódio Sobrinho (2009) obteve as médias: 27,8 para bovinos e 49,2, para suínos. Estes números apenas significam que Alfenas não constituía o pólo mais destacado da pecuária sul mineira oitocentista.

Quanto ao café, presente em 14\% das fazendas arroladas, pode-se dizer que, no período em tela, ele entrava timidamente no município de Alfenas, aparecendo como cultura a mais dentre outras. Em primeiro lugar, convém chamar atenção para a importância das chácaras e das pequenas fazendas na introdução da cafeicultura em Alfenas. Assim, por exemplo, no inventário de Maria Rita Gouvêa, aberto em 2 de setembro de 1873, vê-se que seu viúvo, Joaquim Cassiano de Morais, possuía uma chácara com uma morada de casas coberta de telhas e quintal, no largo da Matriz na Freguesia de Douradinho, na qual plantara um cafezal de valor estimado em 300\$000 (Juízo de Órfãos e Ausentes do Termo de Alfenas. Inv. de Maria Rita Gouvêa, 1873, fl. 5v). Outra chácara com cafezal era a do Major Francisco Gonçalves Leite, situada no largo da Matriz de Alfenas, que possuía casa coberta de telhas, envidraçada e assoalhada, quintal cercado de muros e plantado com muitos pés de café, avaliada em 3:500\$000 (Juízo de Órfãos e Ausentes do Termo de Alfenas. Inv. do Major Francisco Gonçalves Leite, 1890, fl. 11). Já o inventário de João Corrêa do Nascimento, aberto em 13 de julho de 1888, informa que este proprietário possuía um cafezal maltratado na Fazenda Ribeirão de Santo Antônio, avaliado em 300\$000, bem como plantação de café no quintal de sua casa coberta de telhas e assoalhada, situada 
no Arraial de São Sebastião do Areado. Na relação de bens de João Corrêa do Nascimento, há 60 carros de milho no paiol, avaliados em $120 \$ 000$, e 50 alqueires de café em coco, ${ }^{3}$ avaliados em $100 \$ 000-$ o que indica a fatia de renda relativamente maior que o café gerava para o fazendeiro em comparação com o milho (Juízo de Órfãos e Ausentes do Termo de Alfenas. Inv. de João Corrêa do Nascimento, 1888 , fls. 12 e $15 \mathrm{v})$.

Escrituras e procurações também fornecem elementos confirmadores da participação dos pequenos fazendeiros no alvorecer da cultura cafeeira em Alfenas. É o caso do documento seguinte: José Venâncio de Souza, morador de Alfenas, comprou de Custódio Domingues de Miranda, em 5 de junho de 1871, uma "situação", nas margens do Ribeirão São Thomé, na Fazenda de mesmo nome, no Distrito de Alfenas, que possuía casa de morada coberta de telhas, cozinha, monjolo, rego d'água e terreiro de secar café, e mais uma sorte de terras divididas em sociedade na mesma fazenda pelo preço de 1:000\$000 (Cartório do $1^{\circ}$ Ofício, Caixa 1, Livro de Protestos $n^{\circ} 1$, p. $11 \mathrm{v}-12 \mathrm{v}$ ). Interessante notar que José Venâncio de Souza, sete anos depois desta transação, passou procuração, em $1^{\circ}$ de julho de 1878 , para agilizar a venda de dois de seus escravos (Cartório do $1^{\circ}$ Ofício, Caixa 1, Livro 1 de Lançamento de Procurações, p. 98v). Este último documento é sinal de que a cafeicultura parece ter sido implantada em muitas unidades com o concurso da mão de obra escrava. Casos arrolados no Anexo 1 indicam outras fazendas alfenenses nas quais a cultura de café empregou mão de obra cativa. Nesse sentido, os indícios trazem força para o argumento de Maria Lúcia Prado Costa, que assevera incisivamente:

Não se pode dizer - a exemplo da história paulista - que houve marcante substituição da mão de obra escrava pela livre na região. Ao contrário. Escravos, libertos, caipiras e italianos irão disputar em condições bastante similares as adversas condições de trabalho e sobrevivência no Sul de Minas, na segunda metade do século XIX. (Costa, 2002, p. 10)

3 O alqueire, antiga medida de volume, era igual a 36, 27 litros antes de 1874, e a 40 ou 50 litros depois desta data. 
É claro que fazendeiros abastados também tomaram parte na implantação da cafeicultura em Alfenas. Citam-se somente dois casos. O inventário do Capitão Francisco Ferreira de Assis, aberto em 17 de abril de 1875 , informa que este rico proprietário possuía plantações avaliadas em 1:900\$000, distribuídos da seguinte forma: a) batatal no valor de 60\$000; b) dois feijoais no valor de $240 \$ 000$; c) 2 roças de milho no valor de $600 \$ 000$; d) canavial no valor de $600 \$ 000$ e; e) cafezal velho no valor de $400 \$ 000$ (Juízo de Órfãos e Ausentes do Termo de Alfenas. Inv. do Capitão Francisco Ferreira de Assis, 1875, fls. 10-10v). No caso do Capitão Ferreira de Assis, evidentemente, o café constituía mais uma cultura entre outras desenvolvidas na Fazenda da Conquista. Por sua vez, o Coronel Azarias de Souza Dias parecia mais entusiasmado com a cafeicultura, como se pode depreender da notícia publicada no Monitor Sul-Mineiro:

Cultura do Café - O Cel. Azarias comunica ter feito a primeira remessa do café colhido em suas terras, d'onde este ano tirou mais de 2000 arrobas. $\mathrm{O}$ distinto fazendeiro diz-nos mais que na importante freguesia do Machado (...) a colheita há de exceder à 6000 arrobas no decorrente ano, e que em breve tempo esse número subirá a elevada soma. (Monitor Sul-Mineiro, n. 348, 20 de agosto de 1878)

Ainda com relação ao café, uma questão relevante é saber como se faziam a comercialização dos grãos e o financiamento dos cafezais. A este respeito, a documentação compulsada permite inferir algo. Em primeiro lugar, pode-se aventar que parte do financiamento dos cafezais era garantida por capitais de origem local. É o que sugere a procuração passada por Theodoro de Souza Dias, morador do distrito de Machado, em 11 de janeiro de 1876, dando poderes ao Dr. Cândido José Mariano para cobrar de Vicente Ferreira de Oliveira créditos provenientes de um contrato que fez sobre plantações de café (Cartório do $1^{\circ}$ Ofício, Caixa 1, Livro 1 de Lançamento de Procurações, p. 26v-27). Em segundo lugar, no que se refere à comercialização do café produzido no município de Alfenas, há razões para acreditar que muito se fazia por meio de intermediários da própria região. É o que aponta o documento seguinte: Antônio Gonçalves de Araújo, morador da Freguesia da Boa Vista do Termo de Alfenas, no dia 28 de abril de 1878, passou procuração a José Augusto Gilli 
e Antônio de Pádua Pereira Dias para tratar da cobrança do que lhe devia Dona Rachel, francesa, moradora da cidade de Três Pontas. A quantia da dívida referia-se a 40 arrobas de café compradas de Antônio Gonçalves de Araújo por Flávio José Fernandes, em nome de Dona Rachel (Cartório do $1^{\circ}$ Ofício, Caixa 1, Livro 1 de Lançamento de Procurações, p. 92-92v).

\section{As Fortunas Rurais e a Mão de Obra Escrava}

O Anexo 2, relativo à estrutura das fortunas rurais de Alfenas nas décadas de 1850 a 1890, foi construído com base na análise das maiores somas de bens observadas no conjunto de inventários, englobando proprietários que deixaram monte mor bruto igual ou superior a dez contos de réis - 16 inventários (24,6\% do total). O exame deste anexo sugere que, entre os proprietários rurais alfenenses, predominava amplamente o tipo de riqueza velha, para usar a expressão de Zélia Maria Cardoso de Mello (1990), composta por ativos em terras, escravos e dívidas ativas (créditos fornecidos a terceiros, com ou sem prêmio). Entre os 65 inventários analisados, não há sequer uma só referência a títulos da dívida pública ou ações de companhias na lista de bens dos inventariados, fato que demonstra o apego das famílias alfenenses a bens tangíveis (terras, escravos, gado) e a relações creditícias tradicionais.

Uma ideia da variação, no período considerado, da composição dos ativos presentes nos inventários alfenenses é fornecida pela tabela abaixo:

Tabela 3 - \% média dos ativos nos inventários, por década (1850-1880)

\begin{tabular}{|c|c|c|c|c|}
\hline Ativos & Anos 1850 & Anos 1860 & Anos 1870 & Anos 1880 \\
\hline Bens de raiz & 26,03 & 27,32 & 34,00 & 57,92 \\
\hline Cativos & 60,50 & 49,35 & 41,11 & 7,85 \\
\hline Semoventes & 5,41 & 5,75 & 13,60 & 10,82 \\
\hline Dinheiro corrente & 2,18 & 1,95 & 0,36 & - \\
\hline Dívidas ativas & 0,40 & 11,16 & 3,38 & 15,46 \\
\hline Dívidas passivas & 0,94 & 2,72 & 6,56 & 17,81 \\
\hline
\end{tabular}

Fonte: Inventários do Juízo de Órfãos e Ausentes do Termo de Alfenas. 
Observa-se no decorrer do período aumento muito expressivo do item "bens de raiz" na composição da riqueza das famílias alfenenses, o que denota predileção pela terra como investimento e/ou reserva de valor. Também é significativa a ampliação dos "semoventes" na composição dos ativos familiares. Por outro lado, ocorreram quedas enormes na participação do item "cativos" na composição das fortunas, de quase $23 \%$ na virada da década de 1850 para a de 1860 , e de $20 \%$ na virada dos anos 1860 para os anos 1870, algo que contrasta com a Zona da Mata mineira. Esta alteração certamente reflete a proibição do tráfico negreiro e as dificuldades da economia local para, a partir de então, repor a escravaria, bem como a tendência de concentração da escravaria em número cada vez menor de propriedades. ${ }^{4}$

A tabela seguinte sintetiza informações sobre a composição das maiores fortunas rurais:

Tabela 4 - Estrutura das fortunas rurais de Alfenas (1855-1890)

\begin{tabular}{|c|c|c|c|c|}
\hline Ativos/Passivos & Frequência & Menor \% sobre o monte & Maior \% sobre o monte & $\%$ média \\
\hline Bens de raiz & 16 & 4,1 & 92,3 & 40,1 \\
\hline Cativos & 14 & 11,5 & 85,3 & 38,1 \\
\hline Semoventes & 15 & 2,0 & 15,3 & 5,7 \\
\hline Dívidas ativas & 8 & 0,8 & 69,0 & 8,3 \\
\hline Dinheiro corrente & 3 & 2,5 & 8,8 & 0,97 \\
\hline Dívidas passivas & 11 & 0,16 & 25,1 & 3,8 \\
\hline
\end{tabular}

Fonte: Inventários do Juízo de Órfãos e Ausentes do termo de Alfenas.

Chamam atenção no Anexo 2 os itens relativos às dívidas ativas e passivas, que dizem algo sobre a disponibilidade de crédito na economia alfenense. Como se sabe, na economia escravista brasileira, as transações creditícias dependiam das redes de relações sociais construídas pelos agentes econômicos, envolvendo ligações de amizade e parentesco (Florentino e Fragoso, 2001). O financiamento dos cafelistas na Zona da Mata mineira, entre as décadas de 1850 e 1890, conforme mostrou Mônica Oliveira (2005), fluiu por meio desses canais. No caso de Alfenas, os inventários do período 1855-1890 mostram duas coisas interessantes: a) a baixa participação das dívidas ativas (créditos a receber) na composição das fortunas rurais; b) o reduzido grau de endividamento (dívidas passivas) dos fazendeiros

4 Na década de 1850, todas as fazendas inventariadas possuíam escravos. Na década de 1870, 80\% das fazendas inventariadas possuíam escravos e, nos anos 1880, este número baixou para 31\%. 
alfenenses. Ora, a combinação destas variáveis aponta na direção de que os empreendimentos rurais, incluindo suas eventuais expansão e diversificação, dependeram principalmente do autoinvestimento, seja de excedentes gerados pelas atividades agropecuárias, seja de capitais previamente acumulados pelos fazendeiros. O crédito teria circulado pouco no município. Para ilustrar as considerações anteriores, tomam-se os inventários de alguns ricos proprietários alfenenses. Dona Ana Tereza de Souza, cujo inventário foi aberto em 15 de outubro de 1862, casada com José Paulino da Costa, falecera na Fazenda da Vargem Grande do Machadinho. A soma dos bens inventariados do casal alcançou 45:153\$235 rs. O casal não possuía dívidas ativas nem dívidas passivas (Juízo de Órfãos e Ausentes do Termo de Alfenas. Inv. de Ana Tereza de Souza, 1862, fls. 22-22v). O Capitão Francisco Ferreira de Assis, morto no ano de 1875, possuía o maior montemor dentre os inventários arrolados: 194:079\$508 rs. Este poderoso fazendeiro, dono da Fazenda da Conquista, na freguesia de São Francisco do Machadinho, não deixara dívidas passivas. Por outro lado, sua viúva e inventariante, Dona Ana Antônia Pereira, listou 24 devedores, cujas dívidas somavam 29:951\$858 rs (15,4\% do montemor). Dentre os devedores do Capitão, a metade era de pessoas que deviam pequenas quantias na "conta de livro", isto é, ao estabelecimento comercial mantido pelo rico fazendeiro. A outra metade, ao que tudo indica, era de proprietários vizinhos que deviam ao Capitão Francisco Ferreira de Assis quantias variando de 1 a 8 contos de réis (Juízo de Órfãos e Ausentes do Termo de Alfenas. Inv. do Capitão Francisco Ferreira de Assis, 1875, fls. 24-25v e 33).

Caso similar ao do Capitão Francisco Ferreira de Assis é o do pequeno proprietário Antônio Bernardes da Silva, da Fazenda do Gambé, na freguesia de Alfenas. Este senhor, morto em 1860, deixou montemor de 4:628\$203 rs, nenhuma dívida passiva e 2:101\$296 rs $(45,4 \%$ da soma dos bens) de créditos a receber, parte decorrentes da concessão de empréstimos a juros, parte de contas de fregueses existentes no seu pequeno comércio (Juízo de Órfãos e Ausentes do Termo de Alfenas. Inv. de Antônio Bernardes da Silva, 1860, fls. 5v-6 e 16). Já o inventário do Major Francisco Gonçalves Leite, morador de Alfenas, aberto em 27 de maio de 1890, cujo monte-mor foi de 32:133\$840 rs, apresentou a segunda maior proporção (69\%) de dívidas ativas na composição da fortuna dentre os inventários arrolados. As dívidas passivas do Major eram ínfimas, 50\$000, quantia devida a sua própria filha Matilde Gonçalves Leite. As dívidas ativas, que 
totalizavam 21:838\$340 rs, incluíam créditos concedidos a pessoas conhecidas e a parentes. Os créditos ofertados pelo Major aos seus parentes somavam 9:139\$000 rs, ou seja, cerca de 42\% do total de dinheiro a receber pelo inventário (Juízo de Órfãos e Ausentes do Termo de Alfenas. Inv. do Major Francisco Gonçalves Leite, 1890, fls. 11-13v).

Vale registrar o papel de outros agentes econômicos na oferta de crédito local, pessoas que desempenhavam atividades mais especializadas, embora, não raro, possuíssem fazendas. Em 1860, o inventário de Alexandre Carvalho de Macedo, boticário, morador da freguesia de Nossa Senhora do Carmo de Campestre, trouxe a relação dos que lhe deviam. Eram 45 pessoas, tomadoras de empréstimos a juros (que variavam de 1,5 a 1,25\% ao mês). Estas dívidas ativas somavam 39:694\$291 rs, correspondendo a 88\% do monte-mor do boticário (Juízo de Órfãos e Ausentes do Termo de Alfenas. Inv. de Alexandre Carvalho de Macedo, fls. 7v-8). ${ }^{5}$ O médico Amédio Eugênio Silverts, morador de Alfenas que faleceu no ano de 1862, deixou monte-mor de $15: 362 \$ 724$ rs, dos quais $7.609 \$ 084$ rs (quase $50 \%$ ) correspondiam a dívidas ativas - créditos com juros concedidos a quatro pessoas do termo (Juízo de Órfãos e Ausentes do Termo de Alfenas. Inv. do Dr. Amédio Eugênio Silverts, 1862, fl. 8v).

Os valores nominais das dívidas ativas e passivas encontradas nos inventários arrolados, referentes ao período 1855-1890, perfazem cifras relativamente modestas. As dívidas ativas somaram 118:266 \$752 rs. As dívidas passivas 27:857\$289 rs. No total, 146:124\$041 rs circularam sob a forma de crédito, com ou sem prêmios. Mesmo supondo que todos estes créditos inventariados tivessem sido destinados à produção agropecuária, há que considerar a exiguidade destes recursos para suportar movimentos mais robustos de expansão da economia no município de Alfenas. ${ }^{6}$ A implicação disto é que a capacidade de reprodução ampliada das propriedades agrícolas teria esbarrado em limites relativamente estreitos, uma vez que as fortunas encontradas eram inferiores às de outras regiões da Província e do Sudeste.

5 A maior parte dos empréstimos concedidos por Alexandre Carvalho Macedo era de quantias pequenas. Os maiores créditos, 19 transações, variaram entre 1 e 3,4 contos de réis.

6 Para se ter ideia disto, vale lembrar que Warren Dean (1977, p. 47) estimou que o custo de formação de um cafezal com 100 mil cafeeiros, por volta de 1850, na região de Rio Claro (SP), incluindo limpeza das terras, plantação e trato até a maturidade da lavoura e implantação de terreiros de secagem e equipamentos de beneficiamento, em cerca de 50:000\$000. 
Convém examinar agora, ainda que brevemente, o problema da mão de obra rural no município de Alfenas, entre os anos 1850 e 1880. No último quartel do século XIX, a região Sul possuía o segundo maior contingente de escravos da Província de Minas Gerais (Martins, 1980). A Tabela 5 fornece cifras sobre a população escrava do Sul de Minas, comparando-a com as escravarias da Província e da Zona da Mata:

Tabela 5 - População escrava na Zona da Mata e Sul de Minas (1873-1886)

\begin{tabular}{|c|c|c|c|c|c|c|c|c|}
\hline \multirow{2}{*}{ Região } & \multicolumn{2}{|c|}{1873} & \multicolumn{2}{c|}{1880} & \multicolumn{2}{c|}{1884} & \multicolumn{2}{c|}{1886} \\
\cline { 2 - 9 } & Cativos & $\%$ & Cativos & $\%$ & Cativos & $\%$ & Cativos & $\%$ \\
\hline Sul & 81.511 & 21,3 & 71.682 & 22,1 & 63.982 & 21,4 & 61.270 & 21,4 \\
\hline Mata & 100.776 & 26,3 & 100.248 & 30,9 & 106.939 & 35,8 & 104.360 & 36,4 \\
\hline Minas Gerais & 382.640 & 100 & 324.538 & 100 & 298.931 & 100 & 286.491 & 100 \\
\hline
\end{tabular}

Fonte: Martins, 1980, p. 35.

Vê-se que, nas décadas finais do século XIX, a população escrava no Sul de Minas, significativa em relação ao total de cativos da Província, bem como em relação ao total da população regional, ${ }^{7}$ sofreu progressiva redução, ao contrário do que se verificou na Zona da Mata. A intensidade da redução da escravaria sul-mineira, porém, diminuiu na década de 1880 , sinal de que pode ter havido, então, algum impulso na economia regional.

A Tabela 6, por sua vez, reúne informações sobre a escravaria de Alfenas no século XIX, mostrando relativa estabilidade nos números absolutos do contingente mancípio no período 1876-1885:

Tabela 6 - População escrava de Alfenas (1833/35-1885)

\begin{tabular}{|c|c|c|}
\hline Ano & Número de escravos & Variação \% em relação ao ano anterior \\
\hline $1833-35$ & 967 & - \\
\hline 1876 & 4.170 & $+431,2$ \\
\hline 1883 & 5.022 & $+20,4$ \\
\hline 1885 & 4.495 & $-10,5$ \\
\hline 1887 & 1.273 & $-71,7$ \\
\hline
\end{tabular}

Fontes: Para 1833-35, Mapas de população MP-Cx. 05- Doc. 17, Arquivo Público Mineiro. Para 1876, Quadro do Fundo destinado à libertação dos escravos da Província em 1876, in: Revista do Arquivo Público Mineiro, 1979. Para 1883, Monitor Sul-Mineiro, n. 615, de 08/02/1883. Para 1885, Monitor Sul-Mineiro, n. 737, de 01/03/1885. Para 1887, Monitor Sul-Mineiro, n. 849, de 24/04/1887 (escravos matriculados na Coletoria de Alfenas).

7 Roberto Martins (1990, p. 35) calcula que, no ano de 1873, a porcentagem da população escrava em relação à população livre, no Sul de Minas, era de 19\%. 
É interessante notar que, no ano de 1876, Alfenas possuía o oitavo maior contingente de escravos da região Sul de Minas. Em 1883, o município passou a ocupar a quinta posição e, dois anos depois, subiria para o quarto lugar (Costa, 2002, p. 37). Esta variação de posição é indicador de certo dinamismo na economia alfenense, especialmente no território do distrito de Santo Antônio do Machado. ${ }^{8}$

Dentre as quarenta e três fazendas arroladas, trinta e nove foram inventariadas antes da abolição da escravidão. Tomando-se estas 39 propriedades, verifica-se que em 31 delas esteve presente a mão de obra escrava. Os cativos, portanto, trabalharam em $79,5 \%$ das unidades rurais de Alfenas, no período 1855-1888. Esta cifra não deixa espaço para dúvida: o município configurava área de agricultura de abastecimento que empregava cativos às vésperas da abolição do escravismo. As escravarias, contudo, parecem ter se tornado, na segunda metade do século XIX, cada vez mais reduzidas (a média de escravos nas propriedades arroladas era de 6,71 cativos)..$^{9}$ Dentre as escravarias rurais arroladas, 17 (54,8\%) constituíam plantéis pequenos, enquanto 14 eram de plantéis médios. ${ }^{10} \mathrm{~A}$ tabela seguinte mostra a distribuição da posse de cativos entre os fazendeiros alfenenses:

Tabela 7 - Escravarias nas fazendas de Alfenas (1855-1888)

\begin{tabular}{|c|c|c|c|c|}
\hline Tamanho da escravaria & N. & N. cativos & \% total cativos & \% total fazendas com escravos \\
\hline 1 a 5 & 17 & 53 & 25,5 & 54,7 \\
\hline 6 a 10 & 7 & 54 & 25,9 & 22,6 \\
\hline 11 a 15 & 5 & 64 & 30,8 & 16,1 \\
\hline 16 a 20 & 2 & 37 & 17,8 & 6,6 \\
\hline Total & 31 & 208 & 100 & 100 \\
\hline
\end{tabular}

Fonte: Inventários do Juízo de Órfãos e Ausentes do termo de Alfenas.

8 Conforme o Quadro do Fundo destinado à libertação dos escravos da província em 1876, o distrito de Machado, com 1.273 cativos, concentrava mais de 30\% da escravaria do município. A freguesia de São José e Dores de Alfenas tinha 824 escravos; a de Nossa Senhora do Carmo da Escaramuça, 453; a de São Sebastião do Areado, 368; a de São João Batista do Douradinho; 375; e a de São Joaquim da Serra Negra, 877 cativos.

9 Douglas Libby (1988, p. 119) encontrou, para o Sul de Minas, no período 1831-1840, média de escravos por domicílio de 7,6. Expurgados os domicílios com mais de 30 cativos, a média cai para 5,7. Para a Zona da Mata, as médias são, respectivamente, 7,6 e 5,8.

${ }^{10}$ Considera-se aqui que escravarias de 1 a 5 escravos são pequenas, de 6 a 30 escravos são médias e com mais de 30 escravos são grandes escravarias. Ver, por exemplo, Andrade (2008). 
Cabe ressaltar a concentração da posse de escravos, uma vez que $22,7 \%$ das fazendas reuniam $48,6 \%$ de toda a escravaria rural. Neste aspecto, Alfenas não diferia de outras áreas mineiras. Também no que se refere à origem dos cativos, ao sexo e às idades dos integrantes dos plantéis alfenenses, no período em tela, não há diferenças marcantes em relação ao que se observava nas regiões vizinhas (Graça Filho e Pinto, 2006) e em outras áreas da Província (Botelho, 1994; Andrade, 1991). ${ }^{11}$ Estas variáveis demográficas da população escrava do município de Alfenas são mostradas nas Tabelas 8 e 9, que levam em conta todos os registros de escravos nos inventários arrolados, tanto de fazendeiros quanto de não fazendeiros (total de 230 cativos):

Tabela 8 - Origem e sexo dos escravos de Alfenas (1855-1888)

\begin{tabular}{|c|c|c|}
\hline & n. de escravos & $\%$ do total \\
\hline $\begin{array}{l}\quad \text { Origem dos escravos } \\
\text { Brasileiros } \\
\text { Africanos } \\
\text { Sem informação }\end{array}$ & $\begin{array}{c}186 \\
38 \\
06\end{array}$ & $\begin{array}{l}80,8 \\
16,5 \\
2,6\end{array}$ \\
\hline $\begin{array}{l}\text { Sexo dos escravos } \\
\text { Masculino } \\
\text { Feminino }\end{array}$ & $\begin{array}{l}126 \\
104\end{array}$ & $\begin{array}{l}54,8 \\
45,2\end{array}$ \\
\hline
\end{tabular}

Fonte: Inventários do Juízo de Órfãos e ausentes do Termo de Alfenas.

Tabela 9 - Idade dos escravos em Alfenas (1855-1888)

\begin{tabular}{|c|c|c|c|c|c|c|c|}
\hline Décadas & $0-14$ anos & $\%$ & $15-40$ anos & $\%$ & Acima de 40 anos & $\%$ & Sem informação \\
\hline $1850-60$ & 37 & 30,3 & 54 & 44,3 & 27 & 22,1 & 4 \\
\hline 1870 & 32 & 32 & 42 & 42 & 21 & 21 & 5 \\
\hline 1880 & 5 & 62,5 & 2 & 25 & 1 & 12,5 & 0 \\
\hline
\end{tabular}

Fonte: Inventários do Juízo de Órfãos e Ausentes do Termo de Alfenas.

Os dados das últimas tabelas mostram que os senhores de escravos de Alfenas possuíam, nos anos 1850-1880, plantéis com predominância de cativos nascidos no Brasil, em idade ativa e pequena preponderância de homens sobre mulheres. Composição esta que coaduna com a sugestão de Stuart Schwartz $(1988$, p. 290) de que, nas áreas menos fortemente ligadas à economia de exportação, ocorrem meno-

11 É claro que Juiz de Fora, área de hegemonia de grandes propriedades cafeeiras, cujas escravarias possuíam média de 100 cativos, mostrava-se bem diferente do cenário socioeconômico de Montes Claros, área de criação de gado e lavoura de mantimentos, onde predominavam escravarias reduzidas. 
res razões de masculinidade e africanidade, bem como maior número de crioulos, mulheres e crianças. Estes dados também sugerem certa consolidação e estabilidade na composição das escravarias do município, no terceiro quartel dos Oitocentos.

Para o caso dos fazendeiros mais abastados parece haver desproporção entre o tamanho de suas escravarias e as áreas e diversidade de atividades de suas fazendas. Isto significa que certamente havia limites relativamente estreitos para o movimento de reprodução ampliada da economia agrícola de Alfenas, uma vez que, como salientou Jacob Gorender (1985, p. 569), "a acumulação escravista se manifestava, antes de tudo, na acumulação de escravos. Expandir a produção implicava, aqui, em primeiro lugar, o aumento do plantel de escravos". Para a região de Alfenas, provavelmente valem as considerações de Ana Lúcia Duarte Lanna (1983), concernentes à Zona da Mata, sobre a transição para o trabalho livre. ${ }^{12}$ Então, uma questão se coloca: avaliar o peso do trabalhador livre nacional, especialmente de agregados, jornaleiros e meeiros, na dinâmica das fazendas do município, ao longo do período em tela. Todavia, é preciso reconhecer que os inventários não constituem as fontes mais adequadas para se enfrentar tal questão.

\section{O Café na Virada do Século XIX para o Século XX}

Referindo-se às áreas de Machado, Poço Fundo e Douradinho, o Almanach Sul-Mineiro para 1884 (p. 232) afirmava que:

(...) a plantação [de café] é superior a 500 mil pés tendendo a aumentar, pelo que parece terá de predominar na freguesia, outrora exclusivamente entregue à criação de gado e porcos, do que ainda se cuida em escala notável. Cultivam-se também cereais, cana, algodão, fumo, exportando-se de tudo um pouco.

\footnotetext{
${ }^{12}$ Para esta autora, dado o fato de que "a cafeicultura da Zona da Mata não tinha a capacidade de acumulação encontrada no Oeste Paulista" (p. 108), a instauração das relações de trabalho livre não ocorreu por meio do pleno assalariamento, mas pelo predomínio da parceria e do assalariamento temporário.
} 
Vê-se que esta porção do antigo município de Alfenas, na qual a cafeicultura mais favoravelmente vinha se implantando desde os anos 1860, conservava produção agrícola bastante diversificada. A documentação fiscal da Câmara de Machado mostra como a cafeicultura avançou com relativa lentidão no município, embora as rendas provenientes do café já se tornassem dominantes na arrecadação desde o fim dos anos 1890, conforme as tabelas seguintes:

Tabela- Produção cafeeira declarada para fins de tributação-Machado (1899-1912)

\begin{tabular}{|c|c|c|c|}
\hline Ano & N. cafeicultores & N. pés de café & N. arrobas $^{1}$ \\
\hline 1896 & 29 & 294.800 & 22.000 \\
\hline 1901 & 70 & 550.070 & 41.050 \\
\hline 1903 & 74 & 663.970 & 49.550 \\
\hline 1906 & 76 & 974.000 & 73.050 \\
\hline 1909 & 87 & 900.000 & 67.500 \\
\hline 1912 & 96 & 847.000 & 63.525 \\
\hline
\end{tabular}

Tabela - Porcentagem de impostos sobre produção agropecuária Machado (1899-1911)

\begin{tabular}{|c|c|c|c|}
\hline Ano & Imposto Café & Rural & Criação de Gado \\
\hline 1899 & $62 \%$ & $20 \%$ & $18 \%$ \\
\hline 1902 & $66 \%$ & $20 \%$ & $14 \%$ \\
\hline 1905 & $68 \%$ & $20 \%$ & $12 \%$ \\
\hline 1908 & $65 \%$ & $22 \%$ & $13 \%$ \\
\hline 1911 & $62 \%$ & $26 \%$ & $12 \%$ \\
\hline
\end{tabular}

Fontes das tabelas: Códice 73 "Lançamentos de 1899, 1900 e 1901 ”, Códice 74 "Contribuintes dos exercícios de 1902, 1903, 1904 e 1905" e Códice 88 "Contribuintes dos exercícios de 1906-1914". Casa da Cultura de Machado.

No município de Alfenas, a situação do café na virada do século XIX para o XX era menos robusta que em Machado. Pode-se aventar razões para este desenvolvimento relativamente lento da cafeicultura (no sentido da especialização produtiva) em Alfenas e Machado: a) o apego dos fazendeiros à produção agropecuária diversificada; b) a limitada oferta de crédito; c) as dificuldades de transporte (especialmente para o porto de Santos); d) a conjuntura de crise da cafeicultura nacional entre os anos 1898-1906 (Delfim Netto, 1959). A propósito dos efeitos inibidores desta crise na região, pode-se ler no jornal campanhense Monitor Sul-Mineiro, de 31 de março de 1901: "Os cafezais estão sendo abandonados completamente. O desânimo é enorme, já tendo sido aconselhada a triste e infeliz ideia de queimar os cafezais". Quanto ao problema do transporte, no mesmo periódico, na edição de 10 de dezembro de 1907, pode-se ler: 
Se a Cia. Mogyana tornar-se proprietária da [estrada de ferro] Muzambinho, nós machadenses (400 mil arrobas de café exportável, grandes invernadas, plantio crescente de cereais, etc.) e todos os habitantes dos lugares limítrofes, estamos distantes de São Paulo um dia de viagem de estrada de ferro, e (...) consumimos quatro dias em viagem para o Rio de Janeiro (...). Seria muito natural que, estando nós perto da fronteira de São Paulo, o governo, ponderando, resolvesse a situação de modo que protegesse o comércio e a lavoura da região de perto de 200 mil almas, para a qual a proximidade do Porto de Santos fornece extraordinariamente a redução dos fretes.

Ao fim e ao cabo, os últimos dados, combinados com as informações contidas nos inventários examinados, sinalizam no sentido de que, nas terras do antigo município de Alfenas, na segunda metade do século XIX, o café - cujos maiores cafezais tinham de 20 a 40 mil pés - dividiu espaço com grandes invernadas e plantações de cereais, algodão e fumo. ${ }^{13}$

\section{Considerações Finais}

Enfim, é hora de dar um fecho a este texto. Mais do que falar em conclusões, convém colocar algumas hipóteses de trabalho em vista dos indícios recolhidos na documentação mencionada e expostos anteriormente, as quais conduzirão o prosseguimento da pesquisa. Parece fora de dúvida que, no território de Alfenas, entre as décadas de 1850 e 1890, a agropecuária diversificada, voltada para o abastecimento do mercado interno, manteve seu predomínio secular.

A cafeicultura teria sido introduzida na região como mais uma atividade, com a finalidade de aumentar os rendimentos dos fazendeiros

\footnotetext{
${ }^{13}$ Os 6 maiores produtores de café em Machado, listados no exercício de 1896, possuíam em suas fazendas cafezais que variavam de 20,1 mil a 40,2 mil pés (Códice 86 "Contribuintes" do Arquivo da Casa da Cultura de Machado). Quantidades pequenas em comparação com os grandes cafezais de Juiz de Fora e do Oeste Paulista, onde eram comuns plantações com mais de 100 mil pés.
} 
de variadas condições (chacareiros, sitiantes, médios e grandes proprietários). A especialização produtiva em torno cenário do início do século XX muito mais do que às décadas finais do século XIX. Dessa forma, ao cenário econômico do município parece ajustarse como uma luva a afirmação de Francisco Vidal Luna e Herbert S. Klein (2010, p. 304), referente ao Vale do Paraíba paulista da primeira metade do século XIX: "os produtores de milho e outros 'alimentos' ingressaram lentamente na cafeicultura e, enquanto seus cafeeiros amadureciam, provavelmente continuaram a se manter graças à comercialização de produtos tradicionais". Tomados em conjunto, os dados contidos nos Anexos 1 e 2 permitem a construção desta interpretação para a trajetória da economia agrária de Alfenas na segunda metade dos Oitocentos.

Todavia, diferentemente do caso paulista ou da Zona da Mata mineira, as fazendas diversificadas de Alfenas, na fase de implantação da cafeicultura, contaram com escravarias pequenas e médias. No século XIX, o triunfante latifúndio cafeeiro não ditou a regra na vasta área rural de Alfenas e seus distritos. Outra diferença em relação à Zona da Mata mineira parece residir na origem dos agentes responsáveis pela introdução do café. Na Mata, eles foram homens de fortuna que vieram de fora, de zonas vizinhas. No município de Alfenas, tudo indica que os pioneiros da cafeicultura foram proprietários longamente enraizados na região. Fazendeiros muito tradicionais, apegados às formas de "riqueza velha", homens bastante comedidos no uso do crédito, relativamente pouco capitalizados, que lançaram mão principalmente do capital acumulado pelas famílias nos negócios ligados ao abastecimento.

\section{Fontes}

Cartório do $1^{\circ}$ Ofício, Comarca de Alfenas:

Livro 1 de Lançamento das Procurações, Caixa 1.

Livro de Protestos, $n^{\circ} 1$, Caixa 1.

Inventários da Vara de Família e Sucessões da Comarca de Alfenas (acervo do antigo Juízo de Órfãos e Ausentes do Termo de Alfenas).

VEIGA, Bernardo Saturnino da. Almanach Sul Mineiro para 1874. Campanha: Typ. do Monitor Sul-Mineiro, 1874. . Almanach Sul Mineiro para 1884.Campanha: Typ. Do Monitor Sul-Mineiro, 1884. 


\section{Referências}

ANDRADE, M. F. Elites regionais e a formação do Estado Imperial brasileiro: Minas Gerais - Campanha da Princesa (1799-1850). Rio de Janeiro: Arquivo Nacional, 2008.

ANDRADE, R. Escravidão e cafeicultura em Minas Gerais: o caso da Zona da Mata. Revista Brasileira de História, São Paulo, 11(22), mar./ago. 1991.

BARBOSA, Waldemar de Almeida. História de Minas. Belo Horizonte: Comunicação, 1972. Vol. 1.

BOTELHO, T. R. Famílias e escravarias: demografia e família escrava no Norte de Minas Gerais no século XIX. São Paulo: FFLCH/USP, 1994 (Mestrado em História Social).

CARRARA, Angelo Alves. Agricultura e pecuária na capitania de Minas Gerais (1674-1807). Rio de Janeiro: UFRJ, 1997. (Tese de doutorado em História).

COSTA, M. L. P. Fontes para a história social do Sul de Minas: os trabalhadores de Paraguaçu e Machado (1850-1900). Belo Horizonte: Mazza Edições, 2002.

CUSTÓDIO SOBRINHO, J. Negócios internos: estrutura produtiva, mercado e padrão social em uma freguesia sul mineira. Itajubá - 1785-1850. Juiz de Fora: UFJF, 2009 (Dissertação de mestrado em História).

DEAN, W. Rio Claro: um sistema brasileiro de grande lavoura, 1820-1920. Rio de Janeiro: Paz e Terra, 1977.

DELFIM NETTO, Antônio. O problema do café no Brasil. São Paulo, s. ed., 1959.

FILLETO, F. Trajetória histórica do café na região sul de Minas Gerais. Lavras: UFLA, 2000 (Dissertação de mestrado em Administração Rural).

FLORENTINO, Manolo; FRAGOSO, João Luis. O arcaísmo como projeto: mercado atlântico, sociedade agrária e elite mercantil no Rio de Janeiro, c. 1790 - c. 1840. Rio de Janeiro: Civilização Brasileira, 2001.

FRAGOSO, J. L. Homens de grossa aventura: acumulação mercantil e hierarquia na praça mercantil do Rio de Janeiro. Rio de Janeiro: Arquivo Nacional, 1992.

FURTADO, Júnia Ferreira. A morte como testemunho da vida. PINSKY, Carla Bassanezi.

LUCA, Tânia Regina de (Orgs.). O historiador e suas fontes. São Paulo: Contexto, 2009.

GORENDER, J. O escravismo colonial. 4. ed. São Paulo: Ática, 1985.

GOUBERT, P. História local. In: História \& Perspectivas, Uberlândia, jan./jun. 1992, n. 6, pp. 45-57.

GRAÇA FILHO, A. A. A princesa do oeste e o mito de decadência de Minas Gerais. São Paulo: Annablume, 2002.

GRAÇA FILHO, A. A.; PINTO, Fábio Carlos Vieira. Tráfico e famílias escravas em Minas Gerais: o caso de São José do Rio das Mortes (1743-1850). In: PAIVA, Eduardo França; IVO, Isnara Pereira (Orgs.). Escravidão, mestiçagem e histórias comparadas. São Paulo: Annablume, 2006. p. 41-58.

LANNA, A. L. D. A transformação do trabalho. Campinas: Editora Unicamp, 1983.

LENHARO, A. As tropas da moderação. São Paulo: Edições Símbolo, 1979.

LEITE, M. Mineiros e paulistas, plantadores de cidades. São Paulo: Edart, 1961.

LIBBY, D. C. Transformação e trabalho em uma economia escravista, Minas Gerais no século XIX. São Paulo: Brasiliense, 1988.

LIMA, J. H. Café e indústria em Minas Gerais (1870-1920). Petrópolis, RJ: Vozes, 1981.

LUNA, F. V.; KLEIN, H. S. Escravidão africana na produção de alimentos. São Paulo no século 19. Estudos Econômicos, São Paulo, v. 40, n. 2, p. 295-317, abr./jun. 2010.

MARCONDES, R. L. A arte de acumular na economia cafeeira: Vale do Paraíba século XIX. Lorena, SP: Stiliano, 1998. 
MARTINS, R. B. A economia escravista de Minas Gerais no século XIX. Belo Horizonte: CEDEPLAR/ UFMG, 1980.

MARTINS, R. B.; MARTINS, M. C. As exportações de Minas Gerais no século XIX. In: Revista Brasileira de Estudos Políticos, Belo Horizonte, n. 58, 1994.

MELLO, Z. M. C. Metamorfoses da riqueza. São Paulo, 1845-1895. 2. ed. São Paulo: Hucitec, 1990.

MENESES, J. N. C. O continente rústico: abastecimento alimentar nas Minas Gerais setecentistas. Diamantina: Maria Fumaça, 2000.

NOZOE, N.; MOTTA, F. Cafeicultura e acumulação. Estudos Econômicos, São Paulo, v. 24, n. 2, p. 253-320, mai./ago. 1994.

OLIVEIRA, M. R. Negócios de famílias: mercado, terra e poder na formação da cafeicultura mineira - 1780-1870. Bauru, SP: Edusc; Juiz de Fora, MG: FUNALFA, 2005.

PRADO JR., C. Formação do Brasil Contemporâneo. 12. ed. São Paulo: Brasiliense, 1972.

REBELLO, R. M. O município do Machado até a virada do milênio. Machado: s. d., 2006. 2 Vols.

RESENDE, M. E. L. Formação da estrutura de dominação em Minas Gerais: o novo PRM (1889-1906). Belo Horizonte: Editora da UFMG, 1982.

SCHWARTZ, S. B. Segredos internos: engenhos e escravos na sociedade colonial, 1550-1835. São Paulo: Companhia das Letras, 1988.

SILVA, V. A. C. O significado da participação dos mineiros na política nacional, durante a Primeira República. In: V Seminário de Estudos Mineiros. Belo Horizonte: Editora UFMG, 1982.

SINGER, P. Desenvolvimento econômico e revolução urbana. São Paulo: Paz e Terra, 1968.

SLENES, R. W. Os múltiplos de porcos e diamantes: a economia escravista de Minas Gerais no século XIX. Cadernos IFCH UNICAMP, 17, jun. 1985.

SOARES, M. B. Muzambinho: sua história e os seus homens. 1940.

STEIN, S. J. Vassouras: um município brasileiro do café, 1850-1900. Rio de Janeiro: Nova Fronteira, 1990.

IRTH, John D. O fiel da balança: Minas Gerais na Federação Brasileira (1889-1937). Rio de Janeiro: Paz e Terra, 1982. 


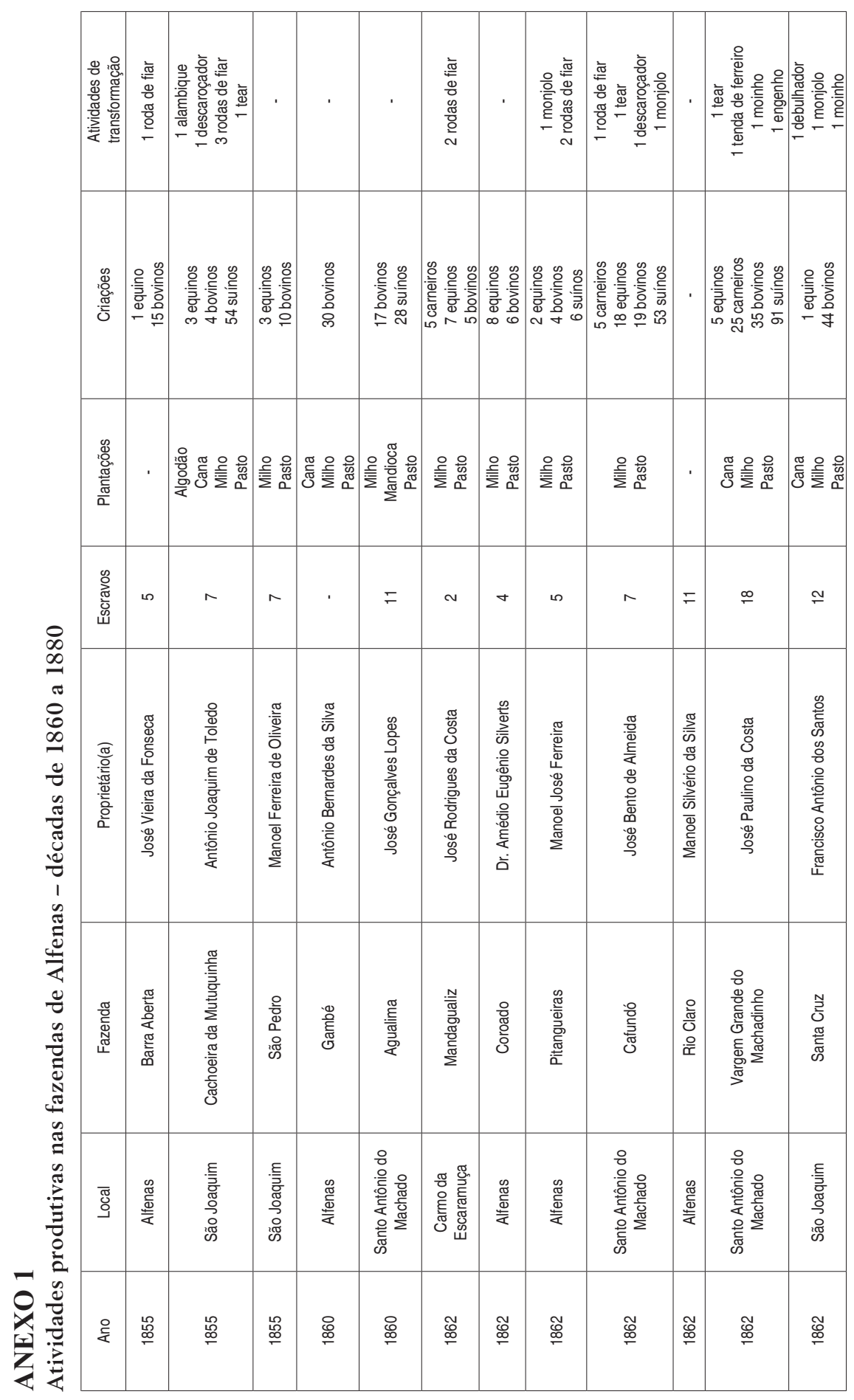

Est. Econ., São Paulo, vol. 43, n.2, p. 397-429, abr-jun. 2013 


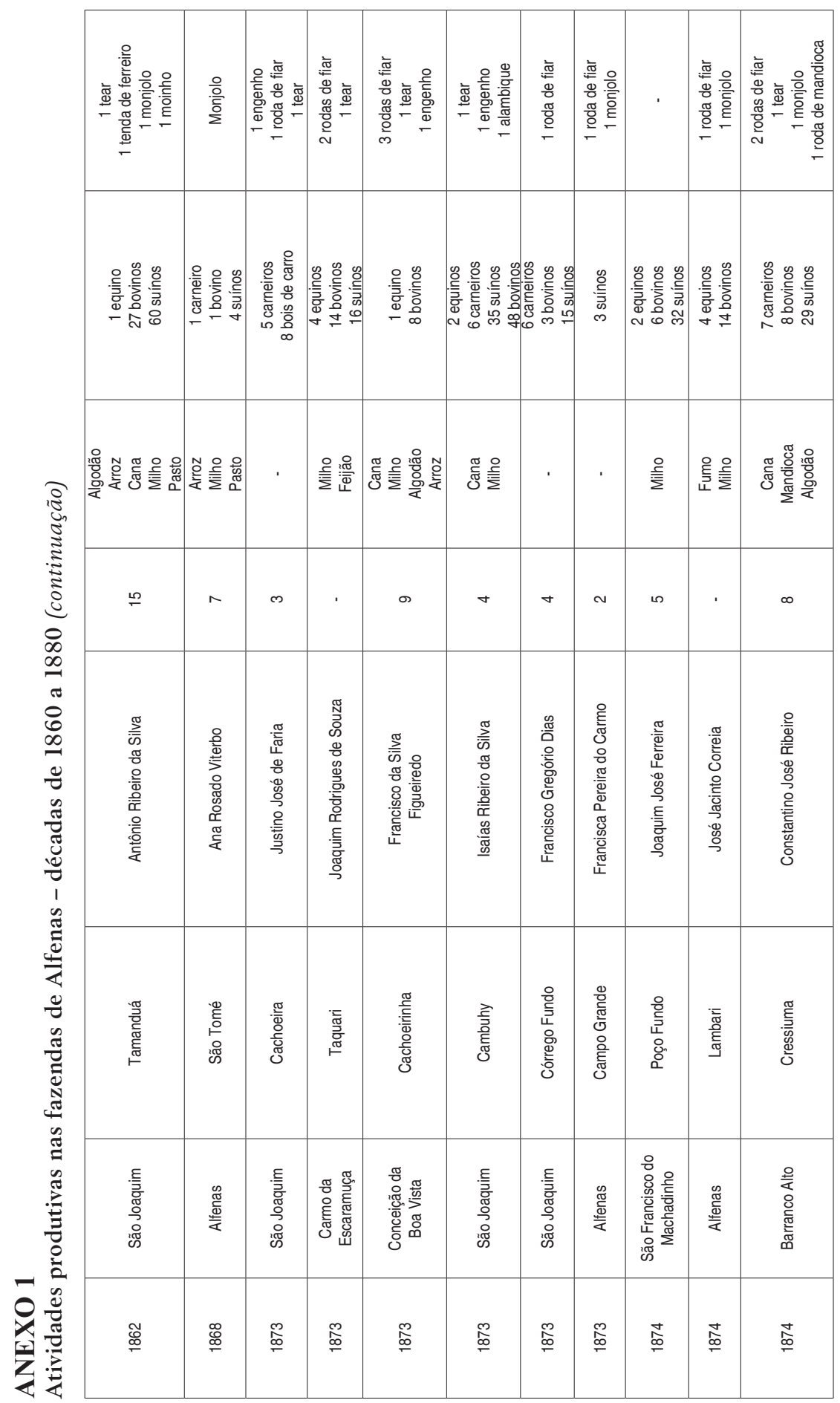

Est. Econ., São Paulo, vol. 43, n.2, p. 397-429, abr.-jun. 2013 


\begin{tabular}{|c|c|c|c|c|c|c|c|c|c|}
\hline 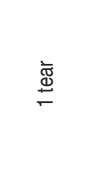 & 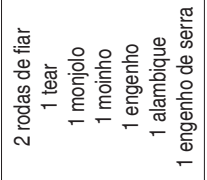 & 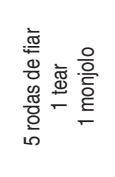 & 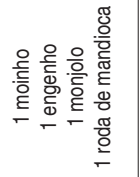 & 蛋 & 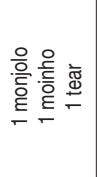 & 응 & 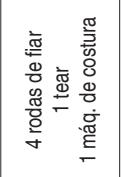 & 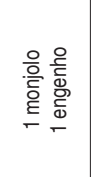 & \\
\hline 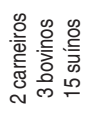 & 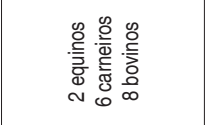 & 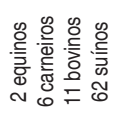 & 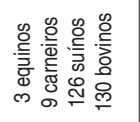 & 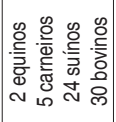 & 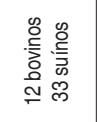 & 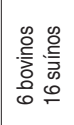 & 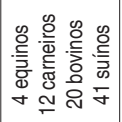 & 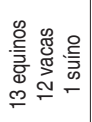 & 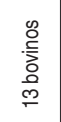 \\
\hline 올 & 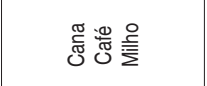 & 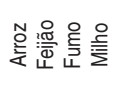 & 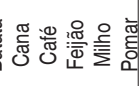 & 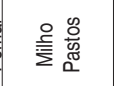 & 을올 & 올윰 & 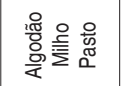 & 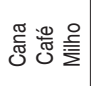 & $\begin{array}{l}\frac{8}{7} \\
\text { o } \\
0\end{array}$ \\
\hline- & $\sigma$ & $\stackrel{2}{2}$ & 우 & $\sim$ & m & . & o & m & $\sim$ \\
\hline 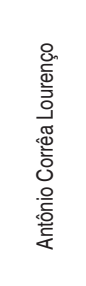 & 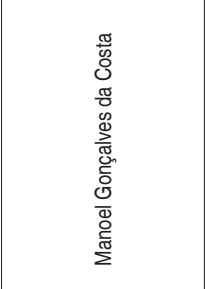 & 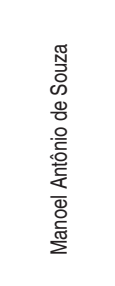 & 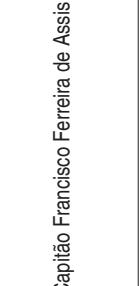 & 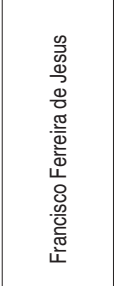 & 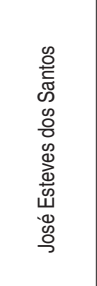 & 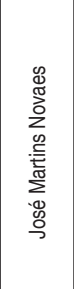 & 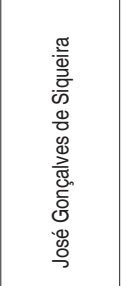 & 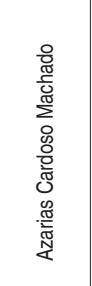 & 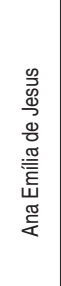 \\
\hline $\begin{array}{l}\frac{}{\pi} \\
\frac{\pi}{0} \\
\frac{0}{\pi}\end{array}$ & 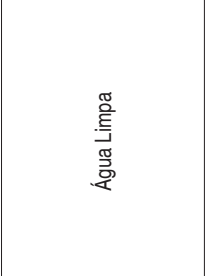 & 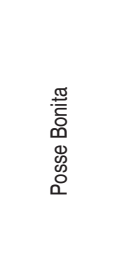 & 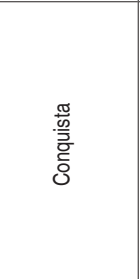 & 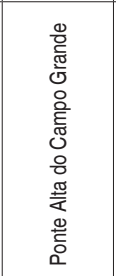 & $\begin{array}{l}\text { 을 } \\
\text { क्ष } \\
\text { o } \\
\text { 일 }\end{array}$ & 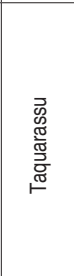 & 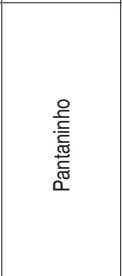 & 递 & 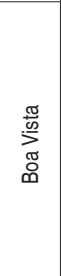 \\
\hline 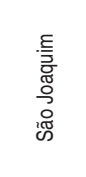 & 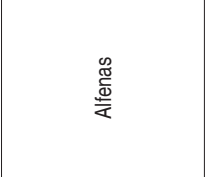 & 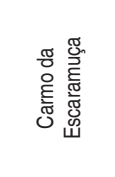 & 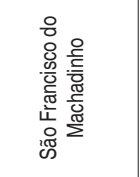 & 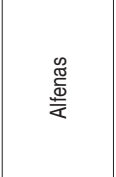 & 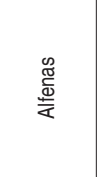 & 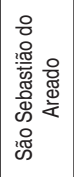 & 㕸 & 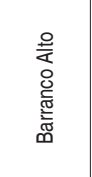 & 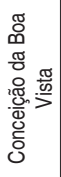 \\
\hline 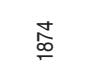 & 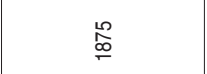 & 岕 $\underset{\infty}{\stackrel{\infty}{\infty}}$ & $\begin{array}{l}\text { 怘 } \\
\stackrel{\infty}{\infty}\end{array}$ & $\begin{array}{l}\stackrel{0}{\infty} \\
\stackrel{\infty}{6}\end{array}$ & $\begin{array}{l}\stackrel{\infty}{\infty} \\
\infty\end{array}$ & 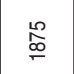 & $\begin{array}{l}\text { 吕 } \\
\text { 足 }\end{array}$ & $\stackrel{\stackrel{0}{\infty}}{\stackrel{\infty}{\infty}}$ & 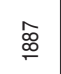 \\
\hline
\end{tabular}




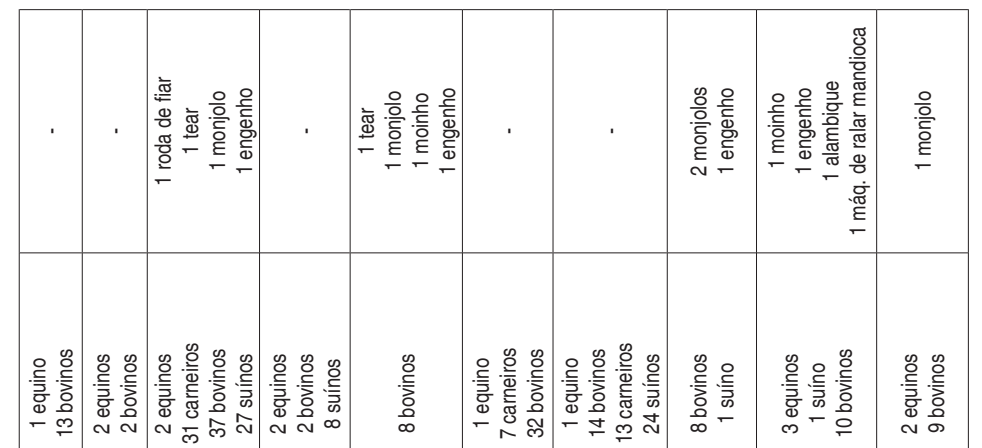

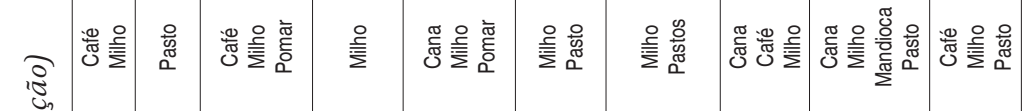

\begin{tabular}{|c|c|c|c|c|c|c|c|c|c|c|}
\hline Ẽ & $\begin{array}{l}\infty \\
\infty \\
\infty \\
\infty \\
\infty \\
\infty \\
\infty\end{array}$ & $\overline{\bar{\alpha}}$ & 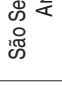 & $\begin{array}{l}\infty \\
\infty \\
\text { का } \\
\text { का }\end{array}$ & 4 & 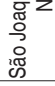 & $\overline{\bar{\alpha}}$ & $\begin{array}{l}\infty \\
\text { is } \\
\text { id } \\
\infty\end{array}$ & ঠू̆ & 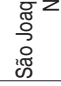 \\
\hline$\frac{x}{2}$ & $\underset{\stackrel{\infty}{\infty}}{\stackrel{N}{c}}$ & 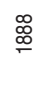 & 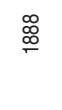 & $\begin{array}{l}\infty \\
\nsubseteq \\
\stackrel{\infty}{0}\end{array}$ & $\begin{array}{l}\stackrel{\infty}{\infty} \\
\stackrel{\infty}{\infty}\end{array}$ & 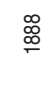 & 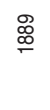 & 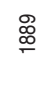 & 吕 & 怘 \\
\hline
\end{tabular}




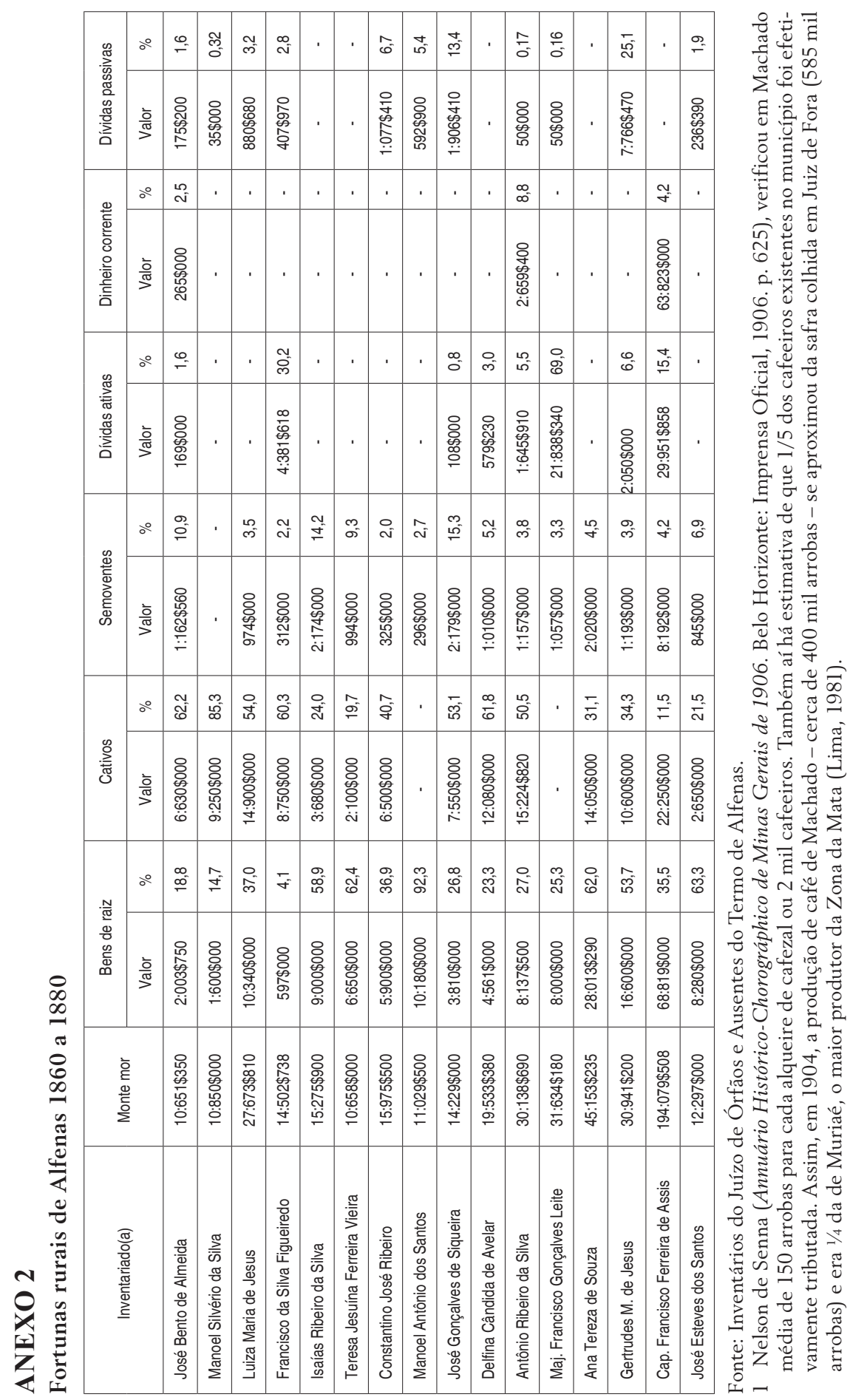

Est. Econ., São Paulo, vol. 43, n.2, p. 397-429, abr-jun. 2013 